\title{
Notch2 signal is required for the maintenance of canine hemangiosarcoma cancer stem cell-like cells
}

\author{
Keisuke Aoshima* (D), Yuki Fukui, Kevin Christian Montecillo Gulay, Ochbayar Erdemsurakh, Atsuya Morita, \\ Atsushi Kobayashi and Takashi Kimura
}

\begin{abstract}
Background: Hemangiosarcoma (HSA) is a malignant tumor derived from endothelial cells which usually shows poor prognosis due to its high invasiveness, metastatic rate and severe hemorrhage from tumor ruptures. Since the pathogenesis of HSA is not yet complete, further understanding of its molecular basis is required.

Results: Here, we identified Notch2 signal as a key factor in maintaining canine HSA cancer stem cell (CSC)-like cells. We first cultured HSA cell lines in adherent serum-free condition and confirmed their CSC-like characteristics. Notch signal was upregulated in the CSC-like cells and Notch signal inhibition by a $\gamma$-secretase inhibitor significantly repressed their growth. Notch2, a Notch receptor, was highly expressed in the CSC-like cells. Constitutive activation of Notch2 increased clonogenicity and number of cells which were able to survive in serum-free condition. In contrast, inhibition of Notch2 activity showed opposite effects. These results suggest that Notch2 is an important factor for maintaining HSA CSC-like cells. Neoplastic cells in clinical cases also express Notch2 higher than endothelial cells in the normal blood vessels in the same slides.
\end{abstract}

Conclusion: This study provides foundation for further stem cell research in HSA and can provide a way to develop effective treatments to CSCS of endothelial tumors.

Keywords: Cancer stem cell-like cells, Hemangiosarcoma, Notch2, Oncology, Tumor Biology

\section{Background}

Hemangiosarcoma (HSA) is a malignant tumor derived from endothelial cells which commonly occurs in dogs (Canis lupus familiaris) [1]. Other animals and humans can have similar tumors but the occurrence is very rare $[1,2]$. Most preferred sites in dogs are the liver, spleen, and right atrium of the heart [3-5]. Patients show poor prognosis due to its aggressive invasion to adjacent tissues, high metastatic rate, and blood loss from tumor ruptures $[6,7]$. Surgical excision of tumor masses or affected organs and chemotherapy are the preferred treatment methods, however, survival time after treatment may not significantly increase $[8,9]$. Furthermore, patients may suffer from severe side effects induced by

\footnotetext{
* Correspondence: k-aoshima@vetmed.hokudai.ac.jp

Laboratory of Comparative Pathology, Department of Clinical Veterinary

Sciences, Faculty of Veterinary Medicine, Hokkaido University, Kita 18 Nishi 9,

Kita-ku, Sapporo, Hokkaido 060-0818, Japan
}

chemotherapeutic drugs such as myelosuppression and cardiotoxicity, which can limit the survival time extension in treated humans and animals $[10,11]$. Therefore, novel effective treatments which can selectively target neoplastic cells have been warranted for decades [9].

Tumors, in general, are composed of many types of cells at various differentiation states and form cellular hierarchy in which cancer stem cells (CSCs) are located at the top [12, 13]. CSCs are a source of neoplastic cells which form tumor masses and are also involved in tumor recurrence after surgical excision, chemotherapy, or radiotherapy $[12,13]$. Therefore, CSCs can be a good therapeutic target to completely eliminate tumors [1315]. Using adult stem cell markers for normal tissues, CSC-like cells have been identified from many types of cancers including leukemia, breast cancer, and melanoma [16-18]. CSCs of HSA, however, have not yet been

(c) The Author(s). 2018 Open Access This article is distributed under the terms of the Creative Commons Attribution 4.0 International License (http://creativecommons.org/licenses/by/4.0/), which permits unrestricted use, distribution, and reproduction in any medium, provided you give appropriate credit to the original author(s) and the source, provide a link to the Creative Commons license, and indicate if changes were made. The Creative Commons Public Domain Dedication waiver (http://creativecommons.org/publicdomain/zero/1.0/) applies to the data made available in this article, unless otherwise stated. 
identified and adult stem cell markers for endothelial cells are also still unknown.

Notch, a type I transmembrane protein, has four identified types (Notch1 to 4). Notch receives signals from neighboring cells expressing the ligands and transduces these signals by translocation of the intracellular domain into the nucleus $[19,20]$. Notch signal is demonstrated to be highly involved in several biological events such as stem cell maintenance, cellular differentiation, angiogenesis, and tumorigenesis [21-24]. CSCs of several types of tumors use Notch signaling to communicate with tumor microenvironment in order to maintain their stemness [25-29]. Notch signal disruption has been reported to be associated with irregular vascular proliferation and vascular tumors in humans and mice [30-32]. Canine HSA is hypothesized to be regulated by the signal transduction, though the role of Notch in HSA has not yet been studied.

The aim of this study was to isolate CSC-like cells from canine HSA cell lines and investigate the role of Notch signaling in HSA CSC-like cells.

\section{Methods}

\section{Cell culture}

We used seven hemangiosarcoma cell lines (JuA1, JuB2, JuB4, Ud2, Ud6, Re12, and Re21) kindly given by Dr. Hiroki Sakai, Gifu University [33]. Human embryonic kidney $293 \mathrm{~T}$ cell line and HeLa cell line derived from human cervical cancer were purchased from RIKEN BioResource Research Center. These cells were cultured with Dulbecco's Modified Eagle's Medium (D-MEM; Wako, Osaka, Japan) supplemented with $10 \%$ fetal bovine serum (FBS; Biowest, UT, USA) and Penicillin/Streptomycin (Thermo Fisher Scientific, MA, USA). For serum free culture, cells were seeded in culture plates coated with $0.1 \%$ gelatin (Wako) and cultured with Dulbecco's Modified Eagle's Medium/ Nutrient Mixture F-12 Ham (Wako) supplemented with $10 \mathrm{ng} / \mathrm{ml}$ basic fibroblast growth factor (bFGF; Wako), $20 \mathrm{ng} / \mathrm{ml}$ epidermal growth factor (EGF; Thermo Fisher Scientific), NS Supplement (Wako) and Penicillin/Streptomycin [34-37]. Cells in both conditions were maintained at $37{ }^{\circ} \mathrm{C}$ with $5 \% \mathrm{CO}_{2}$ prior to use in experiments. Cells were maintained under serum-free condition at least 2 weeks prior to the experiments. Cells were stained with Trypan Blue (Thermo Fisher Scientific) to stain dead cells and only the unstained, viable cells were used for determining cell number.

\section{Notch signal inhibition}

A $\gamma$-secretase inhibitor, N-[N-(3,5-Difluorophenacetyl)-L-alanyl]-S-phenylglycine t-butyl estel (DAPT; Wako), was added to culture medium and dimethyl sulfoxide (DMSO) was used as the control. To find out the appropriate DAPT concentration, expression levels of Notch signal target genes (HES1 and $H E Y 1$ ) were analyzed in HSA cell lines treated with DAPT or DMSO for $48 \mathrm{~h}$. To make the growth curves, $5 \times 10^{3}$ cells were seeded in 12-well plates in triplicate and were cultured in the medium containing $20 \mu \mathrm{M}$ DAPT or DMSO. The cell numbers were counted at each passage point followed by reseeding of $5 \times 10^{3}$ cells into 12 -well plates. This procedure was repeated three or four times and the relative cell number was counted as the cell number at each passage point normalized to the original seeding cell count.

\section{Reverse transcription quantitative polymerase chain reaction ( $R T-q P C R)$}

Total RNA was extracted with TriPure Isolation Reagent (Roche, Basel, Switzerland) according to the manufacturer's instructions. Reverse transcription was performed using Primescript II 1st strand cDNA Synthesis Kit (Takara Bio, Kusatsu, Japan) according to the manufacturer's instructions after treatment with DNaseI (Thermo Fisher Scientific) for 15 mins at room temperature (RT) followed by EDTA treatment for 10 mins at $65{ }^{\circ} \mathrm{C}$. Sample preparation for qPCR was performed using KAPA SYBR FAST qPCR Kit Master Mix (2x) ABI Prism (KAPA Biosystems, MA, USA). Reaction solution contains $1 \times$ KAPA SYBR FAST qPCR Master Mix, $200 \mathrm{nM}$ forward and reverse primers, $1 \mu \mathrm{l} \mathrm{cDNA}$ and UltraPure DNase/RNase-free distilled water (UPDW, Thermo Fisher Scientific). The samples were applied in triplicate and analyzed by StepOne Real-time PCR system (Thermo Fisher Scientific). UPDW and no RT samples were used as negative controls. We confirmed that no signal was detected in the negative controls for all samples. Samples were denatured at $95{ }^{\circ} \mathrm{C}$ for $3 \mathrm{~min}$ followed by 40 cycles of $95^{\circ} \mathrm{C}$ for $3 \mathrm{~s}$ and $60^{\circ}$ $\mathrm{C}$ for $20 \mathrm{~s}$. Results were normalized based on geometric mean of reference genes (GAPDH, ACTB, HMBS). Reference genes were selected from nine potential internal controls (GAPDH, ACTB, B2N, HMBS, HPRT1, RPL13A, RPL32, TBP, YWHAZ) by geNorm software [38, 39]. Primer sequences for qPCR are listed in Table 1. Ensembl and Primer3 softwares were used to design 80 to $150 \mathrm{bp}$ primers which can target all splice variants and cross exon-exon junctions. The BLAST database and software were used to confirm that each primer sequence is not detected in other genes. The HES1 primer and potential internal control primer set sequences were obtained from a journal article published elsewhere [39, 40]. Primer efficiency was calculated based on the slope obtained from each standard curve and was confirmed to be more than $90 \%$ for all primer sequences (Additional files 1 and 2: Figures S1 and S2). Primer set specificity was evaluated by checking that each primer set have identical and singular peak in the melting curve. 
Table 1 Primer list for RT-qPCR

\begin{tabular}{|c|c|c|c|c|}
\hline \multirow[t]{2}{*}{ Primer } & \multicolumn{2}{|l|}{ Sequence } & \multirow{2}{*}{$\begin{array}{l}\text { Gene ID and } \\
\text { references }\end{array}$} & \multirow{2}{*}{$\begin{array}{l}\text { Efficiency } \\
(\%)\end{array}$} \\
\hline & Forward primer & Reverse primer & & \\
\hline$\overline{E R G}$ & CAAACATGACCACGAACGAG & AGGCCGTATTCTTTCACTGC & $\begin{array}{l}\text { ENSCAFG } \\
00000009912\end{array}$ & 98.4 \\
\hline$P R O C R$ & GCAGGAACACAATGCTTCAA & AAGATGCCTACAGCCACACC & $\begin{array}{l}\text { ENSCAFG } \\
00000007945\end{array}$ & 95.5 \\
\hline $50 \times 18$ & TGAACGCCTTCATGGTGTG & GGCGTCAGCTCCTTCCAC & $\begin{array}{l}\text { ENSCAFG } \\
00000029278\end{array}$ & 94.5 \\
\hline FLI1 & TACTGAACAAAGGCCCCAAC & ACTGTCCGAGAGAAGCTCCA & $\begin{array}{l}\text { ENSCAFG } \\
00000032412\end{array}$ & 96.9 \\
\hline NOTCH1 & TACCGGCCAGAACTGTGAGGAGAA & GGAGGGCAGCGGCAGTTGTAAGTA & $\begin{array}{l}\text { ENSCAFG } \\
00000019633\end{array}$ & 93.6 \\
\hline NOTCH2 & TCGGGATAGCTATGAGCCCT & GGCATGTTGCTTTCCCCAAC & $\begin{array}{l}\text { ENSCAFG } \\
00000010476\end{array}$ & 93.6 \\
\hline NOTCH3 & ACAACTGCCAGTGTCCTCCT & GTCCAGCCATTGACACACAC & $\begin{array}{l}\text { ENSCAFG } \\
00000016107\end{array}$ & 93.9 \\
\hline NOTCH4 & AAGCCCTGTCCACACAATTC & CTGGCATAGGGAAGAAGCTG & $\begin{array}{l}\text { ENSCAFG } \\
00000000791\end{array}$ & 95.4 \\
\hline HEY1 & GCGCGGATGAGAATGGAAAC & GTCGGCGCTTCTCAATGATG & $\begin{array}{l}\text { ENSCAFG } \\
00000008391\end{array}$ & 95.3 \\
\hline HEY2 & CGGCGAGATCGGATAAATAA & CGCGTCGAAGTAGCCTTTAC & $\begin{array}{l}\text { XM_541232.5 } \\
\text { ENSCAFG } \\
00000032212\end{array}$ & 96.4 \\
\hline HES1 & CATCCAAGCCTATCATGGAGA & GTTCCGGAGGTGCTTCACT & Dailey DD et al. & 95.5 \\
\hline HES6 & CAGGCCAAGCTGGAGAAC & GCATGCACTGGATGTAGCC & $\begin{array}{l}\text { ENSCAFG } \\
00000012428\end{array}$ & 96.5 \\
\hline NRARP & TGAAGCTGCTGGTCAAGTTC & CTTGGCCTTGGTGATGAGAT & $\begin{array}{l}\text { ENSCAFG } \\
00000019445\end{array}$ & 94.5 \\
\hline FCER2 & GAGGAGGTGGAGAAGCTGTG & CCTCGCCGAAGTAGTAGCAC & $\begin{array}{l}\text { ENSCAFG } \\
00000030055\end{array}$ & 97.5 \\
\hline GAPDH & ATTCCACGGCACAGTCAAG & TACTCAGCACCAGCATCACC & $\begin{array}{l}\text { ENSCAFG } \\
00000015077\end{array}$ & 99.5 \\
\hline$A C T B$ & CCAGCAAGGATGAAGATCAAG & TCTGCTGGAAGGTGGACAG & $\begin{array}{l}\text { ENSCAFG } \\
\text { 00000016020 } \\
\text { Peters IR. et al. }\end{array}$ & 98.8 \\
\hline HMBS & TCACCATCGGAGCCATCT & GTTCCCACCACGCTCTTCT & $\begin{array}{l}\text { ENSCAFG } \\
\text { 00000012342 } \\
\text { Peters IR. et al }\end{array}$ & 95.8 \\
\hline RPL13A & GCCGGAAGGTTGTAGTCGT & GGAGGAAGGCCAGGTAATTC & $\begin{array}{l}\text { ENSCAFG } \\
\text { 00000029892 } \\
\text { Peters IR. et al }\end{array}$ & 98.2 \\
\hline RPL32 & TGGTTACAGGAGCAACAAGAAA & GCACATCAGCAGCACTTCA & $\begin{array}{l}\text { ENSCAFG } \\
00000004871 \\
\text { Peters IR. et al }\end{array}$ & 95.9 \\
\hline HPRT1 & CACTGGGAAAACAATGCAGA & ACAAAGTCAGGTTTATAGCCAACA & $\begin{array}{l}\text { ENSCAFG } \\
\text { 00000018870 } \\
\text { Peters IR. et al }\end{array}$ & 95.7 \\
\hline$B 2 M$ & ACGGAAAGGAGATGAAAGCA & CCTGCTCATTGGGAGTGAA & $\begin{array}{l}\text { ENSCAFG } \\
\text { 00000013633 } \\
\text { Peters IR. et al }\end{array}$ & 98.2 \\
\hline YWHAZ & CGAAGTTGCTGCTGGTGA & TTGCATTTCCTTITTGCTGA & $\begin{array}{l}\text { ENSCAFG } \\
\text { 00000000580 } \\
\text { Peters IR. et al }\end{array}$ & 93.4 \\
\hline$T B P$ & ATAAGAGAGCCCCGAACCAC & TTCACATCACAGCTCCCCAC & $\begin{array}{l}\text { ENSCAFG } \\
00000004119 \\
\text { Peters IR. et al }\end{array}$ & 97.3 \\
\hline
\end{tabular}




\section{Colony formation assay (CFA)}

One thousand cells were seeded in 6-well culture plates and were cultured until the diameter of the biggest colony reached $2 \mathrm{~mm}$. Cells were fixed with $4 \%$ paraformaldehyde for 20 mins at RT and then stained with Crystal Violet (Sigma-Aldrich, MO, USA) for 30 mins at RT. After washing with phosphate buffered saline (PBS) and drying at $\mathrm{RT}$, colonies were visualized using an inverted microscope (Eclipse TS100; Nikon, Tokyo, Japan) and colonies which have more than 50 cells were counted [41].

\section{Chemoresistance assay}

Three (normal culture) or five (serum-free culture) thousand cells seeded in 96-well culture plates and were treated with either DMSO, doxorubicin (Wako) or paclitaxel (Wako) at increasing concentrations the following day. Soon after the treatments, culture medium in each cell lines were collected and the absorbance at the time of treatment $(\mathrm{Tz})$ was measured. Seventy-two hours after treatment, cell viability was analyzed using Cell Counting Kit-8 (Dojindo, Kumamoto, Japan) according to the manufacturer's instructions. The absorbance of each well $72 \mathrm{~h}$ after treatments $(\mathrm{Ti})$ was measured at $450 \mathrm{~nm}$ using NanoDrop 2000 (Thermo Fisher Scientific). DMSO treated cells were used as the control $(\mathrm{C})$. Growth inhibition rates were measured as: $[(\mathrm{Ti}-\mathrm{Tz}) /(\mathrm{C}-\mathrm{Tz})] \times 100$ for concentrations in which $\mathrm{Ti}>/=\mathrm{Tz},[(\mathrm{Ti}-\mathrm{Tz}) / \mathrm{Tz}] \times 100$ for concentrations in which $\mathrm{Ti}<\mathrm{Tz}$ [42].

\section{Aldehyde dehydrogenase (ALDH) assay}

To analyze ALDH activity, ALDEFLUOR kit (STEMCELL technologies, Vancouver, Canada) was used according to the manufacturer's instructions. We stained $5 \times 10^{5}$ cells with ALDEFLUOR reagent for 50 mins at $37^{\circ} \mathrm{C}$. N,N-diethylaminobenzaldehyde (DEAB) was used to inhibit ALDH activity and $\mathrm{DEAB}$ treated cells were used as basis to gate ALDH positive population. The cells were analyzed using FACSVerse (Becton Dickinson, NJ, USA) after excluding the dead cells which were positive for 7-aminoactinomycin D (Thermo Fisher Scientific). The data was analyzed using FACSuite software (Becton Dickinson).

\section{Protein extraction and western blotting}

Cells were lysed using Radioimmunoprecipitation buffer [RiPA buffer; $50 \mathrm{mM}$ Tris- $\mathrm{HCl}$ (pH 8.0), $150 \mathrm{mM} \mathrm{NaCl}$, $0.1 \%$ TritonX-100, $0.1 \%$ sodium dodecyl sulfate (SDS), $0.5 \%$ sodium deoxycholate, EDTA-free proteinase inhibitor cocktail (Sigma-Aldrich)]. Protein concentration was measured using Pierce BCA Protein Assay Kit (Thermo Fisher Scientific) according to the manufacturer's instruction. Samples were denatured by adding $1 / 4$ volume of $4 \times$ Sample buffer [200 mM Tris-HCl buffer (pH 6.8), 8\% SDS, 40\% Glycerol, $1 \%$ bromophenol blue, 20\% 2-mercaptoethanol] to each sample followed by incubation at $98{ }^{\circ} \mathrm{C}$ for 5 mins. Ten micrograms proteins were separated in 8\% SDS polyacrylamide gels by electrophoresis and were transferred to polyvinylidene difluoride membrane (PVDF membrane: Merck Millipore, MA, USA) using Mini Trans-Blot Cell (BIO-RAD, CA, USA). Membranes were then blocked in $5 \%$ skim milk in Tris-buffered saline containing $0.05 \%$ Tween 20 (TBST) for $1 \mathrm{~h}$ at RT. Membranes were either incubated with anti-human Notch2 intracellular domain antibody (R\&D systems, MN, USA; 1:2000), anti-FLAG M2 monoclonal antibody (Sigma-Aldrich; 1:1000) or anti-Actin antibody clone C4 (Merck Millipore; 1:10,000) overnight at $4{ }^{\circ} \mathrm{C}$. After washing with TBST, membranes were incubated with donkey anti-goat IgG-HRP (Santa cruz, TX, USA; 1:5000) or ECL Mouse IgG HRP-linked whole antibody (GE Healthcare, IL, USA; $1: 10,000)$ for $1 \mathrm{~h}$ at RT. After washing with TBST, signals were visualized with Immobilon Western Chemiluminescent HRP substrate (Merck Millipore) and detected by ImageQuant LAS 4000 mini (GE Healthcare). Images were processed with ImageJ software [43-45].

\section{Plasmid construction}

Canine NOTCH2 gene (ENSCAFG00000010476) cloned from the cDNA of Canine Aortic Endothelial Cells (CnAOEC; Cell Applications, CA, USA) was subcloned into a self-inactivating (SIN) lentiviral vector construct, CSII-CMV-MCS-IRES2-Bsd. To make the dominant negative form and constitutive active form of Notch2, 1$5343 \mathrm{bp}$ and $5161-7413 \mathrm{bp}$ of NOTCH2 were amplified from full length $\mathrm{NOTCH} 2$ gene, respectively [46]. These two mutants were also subcloned into the SIN lentiviral vector construct. FLAG sequences were added at the C-terminus of full length and mutant Notch2 constructs by inverse PCR.

\section{Lentivirus infection}

We seeded $8 \times 10^{5} 293 \mathrm{~T}$ cells in a $6 \mathrm{~cm}$ dish and cultured in antibiotic-free medium. Cells were transfected, using Lipofectamine 3000 (Thermo Fisher Scientific) according to the manufacturer's instructions, with three constructs; a packaging construct (pCAG-HIVgp), a VSV-G and Rev expressing construct (pCMV-VSV-G-RSV-Rec) and SIN lentiviral vector constructs. Forty-eight hours after transfection, culture media containing the produced viruses were collected in $15 \mathrm{~mL}$ tubes and centrifuged at $6000 \mathrm{~g}$ for $16 \mathrm{~h}$ at $4{ }^{\circ} \mathrm{C}$. Pellets were resuspended in normal culture medium and used as virus reagent. Cells were cultured in the virus reagent with $8 \mu \mathrm{g} / \mathrm{ml}$ Polybrene (Sigma-Aldrich). Eight hours after infection, the medium in cell culture wells was replaced with a fresh medium without the viruses. Forty-eight hours later, culture medium was changed to normal medium supplemented with $10 \mu \mathrm{g} / \mathrm{ml}$ Blasticidin for selection and the cells were maintained for future experiments. 


\section{Immunohistochemistry (IHC)}

Twelve canine HSA cases collected from Hokkaido University Veterinary Teaching Hospital were used for IHC. These cases were derived from the spleen, liver, kidney and thoracic cavity (Table 2). Tissue samples were processed routinely as described previously [47]. The slides were immersed in $10 \mathrm{mM}$ sodium citrate buffer ( $\mathrm{pH}$ 6.0), boiled for 15 mins in a microwave for antigen retrieval and then cooled down to RT. After washing with PBS, sections were treated with $0.3 \% \mathrm{H}_{2} \mathrm{O}_{2}$ in methanol for 15 mins at RT to inactivate endogenous peroxidases followed by blocking with $10 \%$ rabbit normal serum (Nichirei biosciences, Tokyo, Japan) for $1 \mathrm{~h}$ at RT. Sections were incubated with anti-human Notch2 intracellular domain antibody (R\&D systems; $1: 40$ ) for overnight at $4{ }^{\circ} \mathrm{C}$. PBS instead of the primary antibody was added to the negative controls. After washing with PBS, sections were treated with biotinylated anti-goat IgG (Nichirei biosciences) for $1 \mathrm{~h}$ at RT followed by incubation with peroxidase conjugated streptavidin (Nichirei biosciences) for 10 mins at RT. After washing with PBS, signal detection was carried out by submerging the sections in freshly prepared solution of 3,3'-diaminobenzidine tetrahydrochloride (Dojindo, Kumamoto, Japan) for 5 mins, and the sections were counterstained with hematoxylin for $1 \mathrm{~min}$ and then dehydrated and mounted with cover glasses. Signals were captured with BX63 microscope (Olympus, Tokyo, Japan) and processed with ImageJ software.

\section{Statistical analyses}

For the comparison of gene expression between two samples, Student's $t$ test was performed. Dunnett's test was used in comparing the effects of Notch2 and Notch2 mutant expressions with empty vector-infected cells as the control.

Table 2 Case information

\begin{tabular}{lllll}
\hline Case No. & Breed & Age & Sex & Location \\
\hline 1 & Labrador retriever & $10 y$ & Spayed female & Spleen, Liver \\
2 & Border Collie & $13 y$ & Male & Spleen \\
3 & Maltese & $10 y$ & Male & Spleen \\
4 & Scottish terrier & $10 y$ & Spayed female & Thoracic cavity \\
5 & Miniature dachshund & $11 y$ & Female & Spleen, Liver \\
6 & Golden retriever & $9 y$ & Spayed female & Spleen \\
7 & Miniature schnauzer & $11 y$ & Male & Spleen \\
8 & Golden retriever & $9 y$ & Castrated Male & Liver \\
9 & Bichon frise & $8 y$ & Spayed female & Kidney \\
10 & Labrador retriever & $10 y$ & Male & Spleen \\
11 & Great pyrenees & $10 y$ & Castrated Male & Spleen \\
12 & Golden retriever & $9 y$ & Male & Spleen \\
\hline
\end{tabular}

\section{Results}

HSA cell lines in serum-free culture condition have CSClike characteristics

To isolate CSC-like cells from HSA cell lines, we cultured HSA cell lines in adherent serum-free (SF) culture condition in gelatin-coated cell culture plates. Approximately $70-90 \% \mathrm{Ju}$ and Ud cells died within 2 days after culturing and surviving cells proliferated slowly. On the other hand, Re cells did not survive in this condition. Next, we checked expression levels of undifferentiated endothelial cell-related genes: ERG, PROCR, SOX18 and FLI1 (Fig. 1a) [48-50]. Prior to qPCR analysis, reference gene sets were selected from nine potential internal controls (GAPDH, ACTB, B2M, HMBS, HPRT1, RPL13A, RPL32, TBP, YWHAZ) using geNorm software (Additional file 3: Figure S3) [38, 39]. Based on the analysis, three reference genes (GAPDH, ACTB, HMBS) were selected and the geometrical mean of the expression levels of these genes was used as a control for normalization. $E R G$ and PROCR were upregulated in all cell lines except for PROCR in JuA1. SOX18 was highly expressed in JuB4, Ud2 and Ud6. FLI1 was upregulated in JuB4 and Ud6. No significant repression of these genes was detected in SF condition except for PROCR in JuA1. We also analyzed the clonogenicity of HSA cells in serum-free condition using CFA. All cell lines cultured in SF condition had significantly increased number of colonies compared to cell lines cultured in normal condition (Fig. 1b).

Since cancer stem cells have higher resistance to anti-cancer drugs, we analyzed sensitivities of HSA cell lines to doxorubicin and paclitaxel in normal and SF conditions $[12,13]$. All cell lines cultured in SF condition had significantly higher resistance to both chemotherapeutic drugs although the extents vary between cell lines (Fig. 2). ALDH is known as one of the CSC markers highly associated with drug resistance capability, hence, ALDH activities were analyzed [51, 52]. Flow cytometry analysis revealed that the percentage of ALDH positive cells were significantly increased in SF condition except for Ud2 (Fig. 3).

These results suggest that HSA cells isolated by our SF culture method have CSC-like characteristics.

\section{Notch2 signal is required for HSA CSC-like cell survival in serum-free culture condition}

We succeeded in isolating CSC-like cells from HSA cell lines but the genes nor the factors which are important for these cells' survival were still unclear. Notch signal has been previously reported as a necessary signal transduction for tumor development, stem cell maintenance including CSCs, and angiogenesis [19-28]. Dysregulation of Notch signal has been associated with vascular tumors in humans and mice [30-32]. Thus, we tried to 

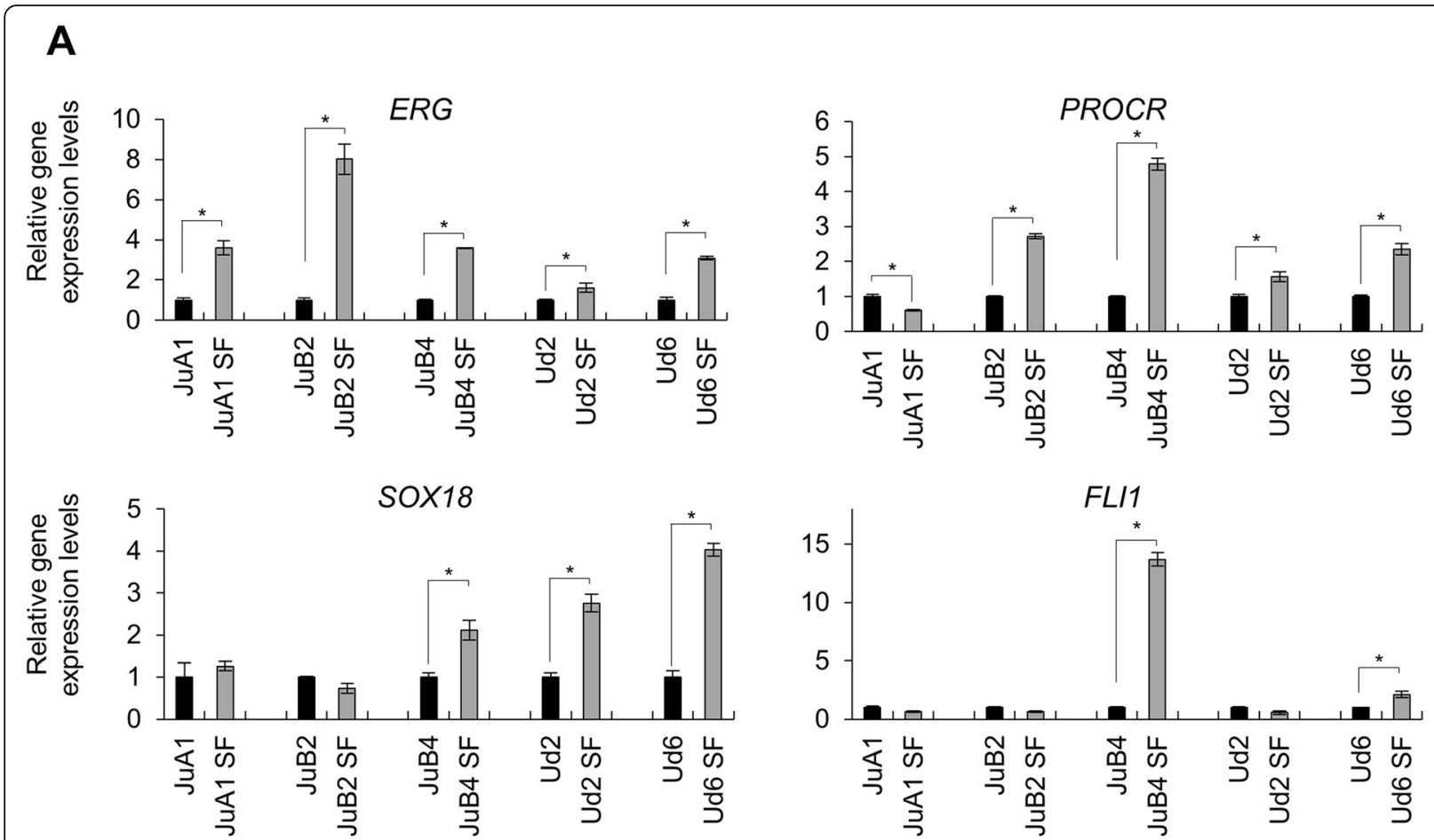

B
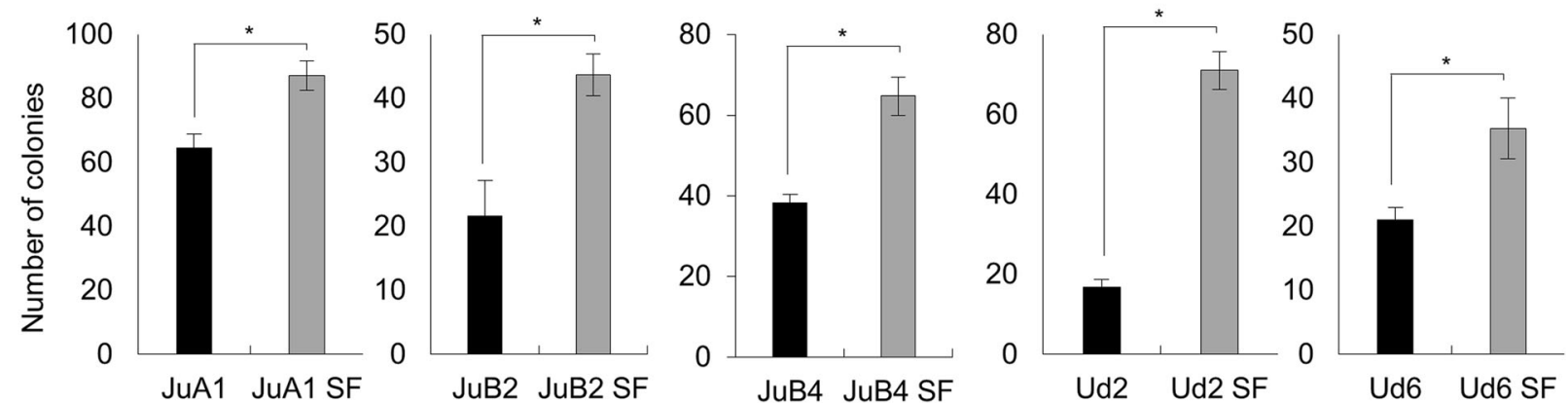

Fig. 1 a Expression levels of undifferentiated endothelial cell-related genes in HSA cell lines cultured in normal or in SF conditions. Gene expression levels of each cell line in normal condition were set to 1 . $\mathbf{b}$ The numbers of colonies of each cell line and condition. ${ }^{*} p<0.01$. Student's $t$ test. All samples were analyzed in triplicates and the scores are presented as means \pm SD

investigate its function in HSA cell lines. First, we analyzed gene expression levels of Notch receptors (NOTCH1, NOTCH2, NOTCH3 and NOTCH4) and Notch target genes (NRARP, HEY2, HES6 and FCER2) in normal and in SF conditions. NOTCH2 and NOTCH4 were upregulated in SF condition in all cell lines except for NOTCH2 in Ud6, in addition, at least two target genes were expressed higher in SF condition than normal condition (Fig. 4a and b). To check the Notch2 function in HSA cell growth, we tried to inhibit the function with a $\gamma$-secretase inhibitor, DAPT. We tested DAPT for HSA cell lines at several concentration and found out that $20 \mu \mathrm{M}$ DAPT was enough to repress Notch signal target gene expression (Additional file 4:
Figure S4) and was therefore used for further experiments. In normal condition, all cell lines except for JuB2 did not show any significant decrease in growth rate after DAPT treatment when compared to the control (Fig. 5a). In contrast, all cell lines in SF condition had dramatically decreased growth rate after treatment with DAPT (Fig. 5a and b). These results suggest that Notch signal is required for HSA cell survival in SF condition.

Although NOTCH2 and NOTCH4 were upregulated in SF condition (Fig. 4a), $2^{-\Delta \mathrm{Ct}}$ values of $\mathrm{NOTCH} 2$ was much higher than that of NOTCH4 (Table 3). In addition, Notch2 specific target FCER2 was upregulated, which encouraged us to analyze the effects of Notch2 in HSA cell lines. Prior to examining Notch2 protein 

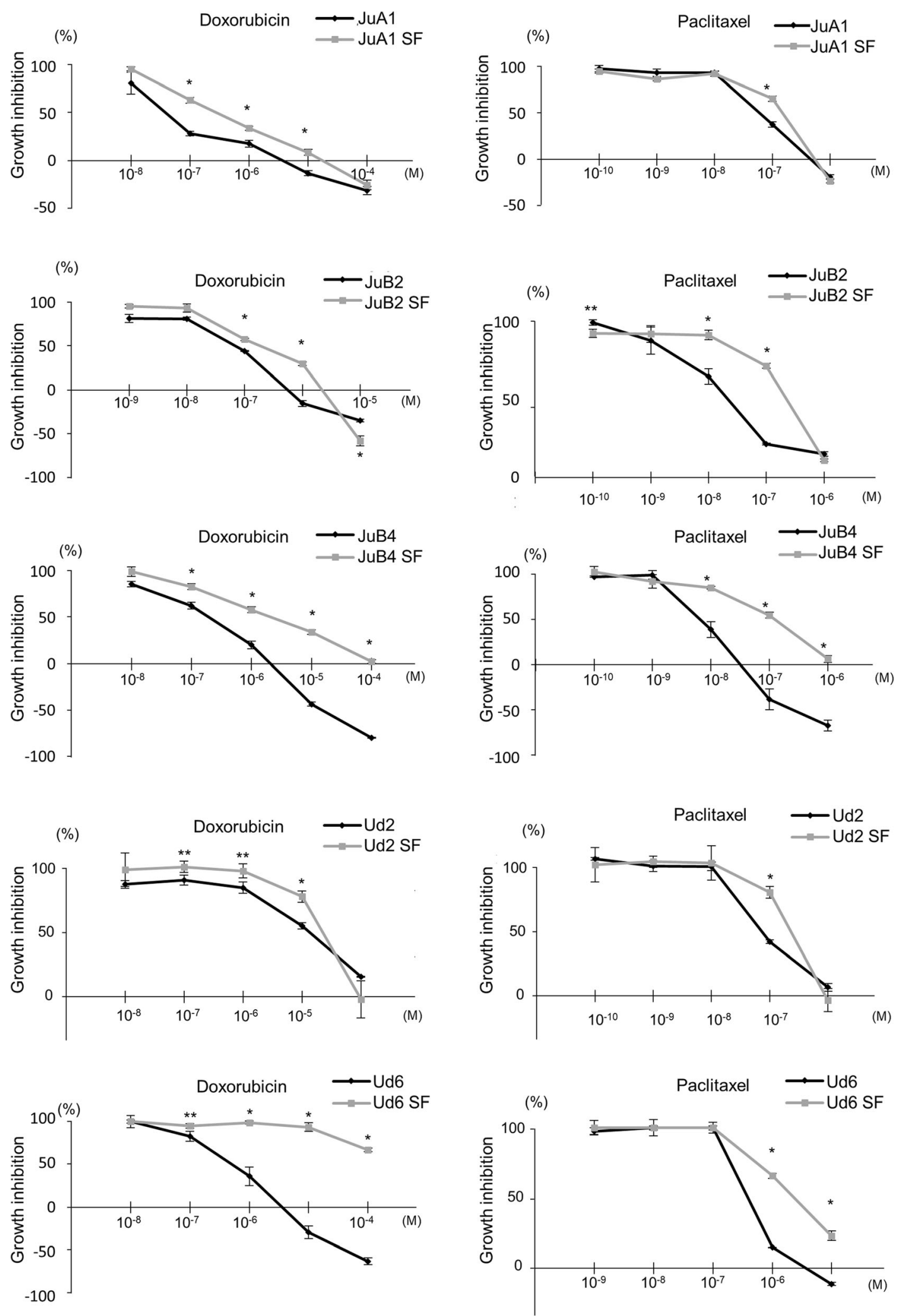

Fig. 2 Survival rate of HSA cell lines treated with doxorubicin or paclitaxel. ${ }^{*} p<0.01$. ${ }^{*} p<0.05$. Student's $t$ test. All samples were analyzed in triplicates. Survival curves are plotted as average percentages \pm SD 


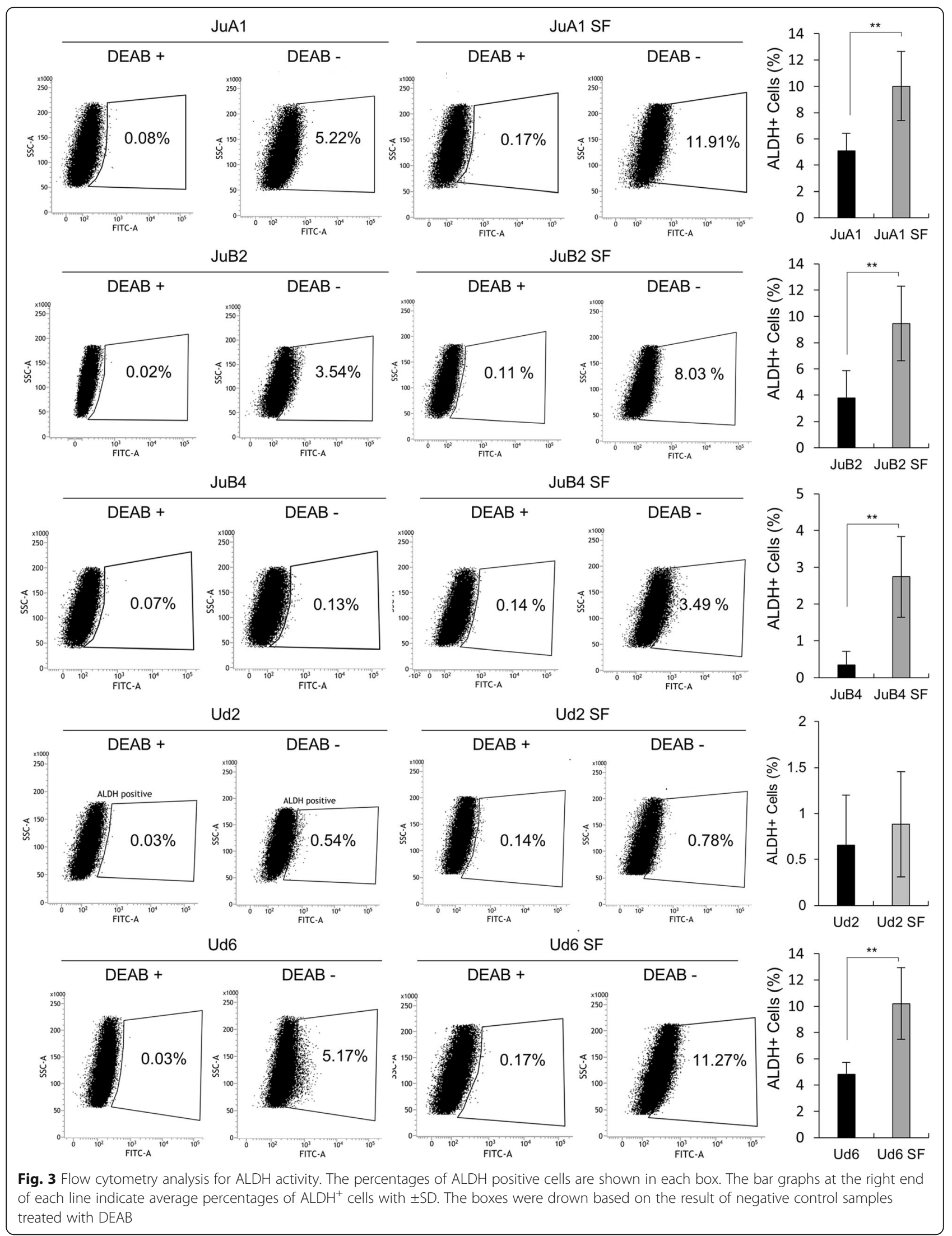




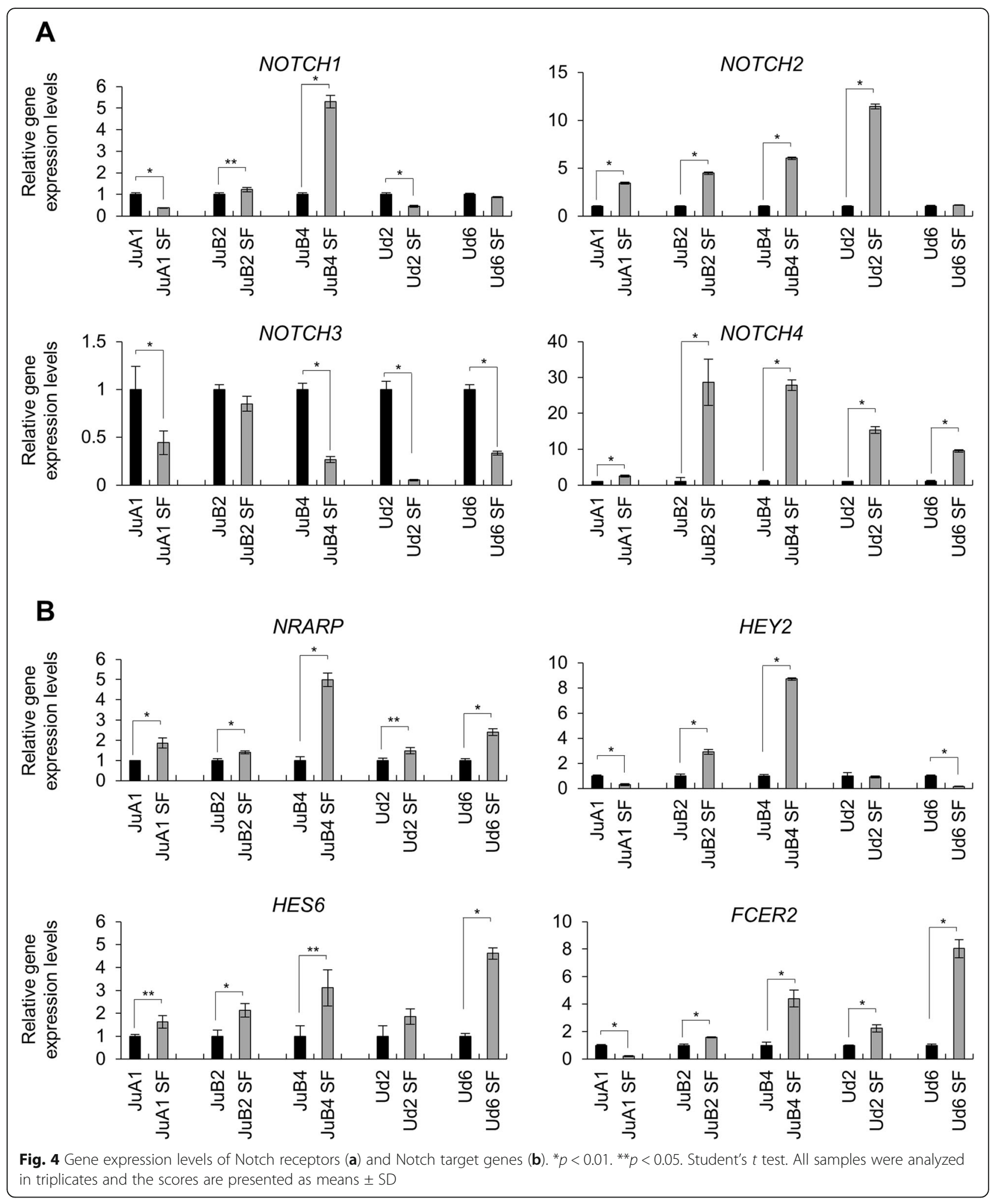

expression, we confirmed that anti-human Notch2 antibody can cross-react with canine Notch2 (Fig. 6a). Notch2 protein expression was higher in SF condition than the normal condition (Fig. 6b). Based on previous research, we constructed lentiviral vectors to stably express Notch2 full length form (FL), dominant negative form (Ex) and constitutive active form (In) in JuB2, Ud6, and Re12 in normal culture condition (Fig. 6c) [46]. 
A
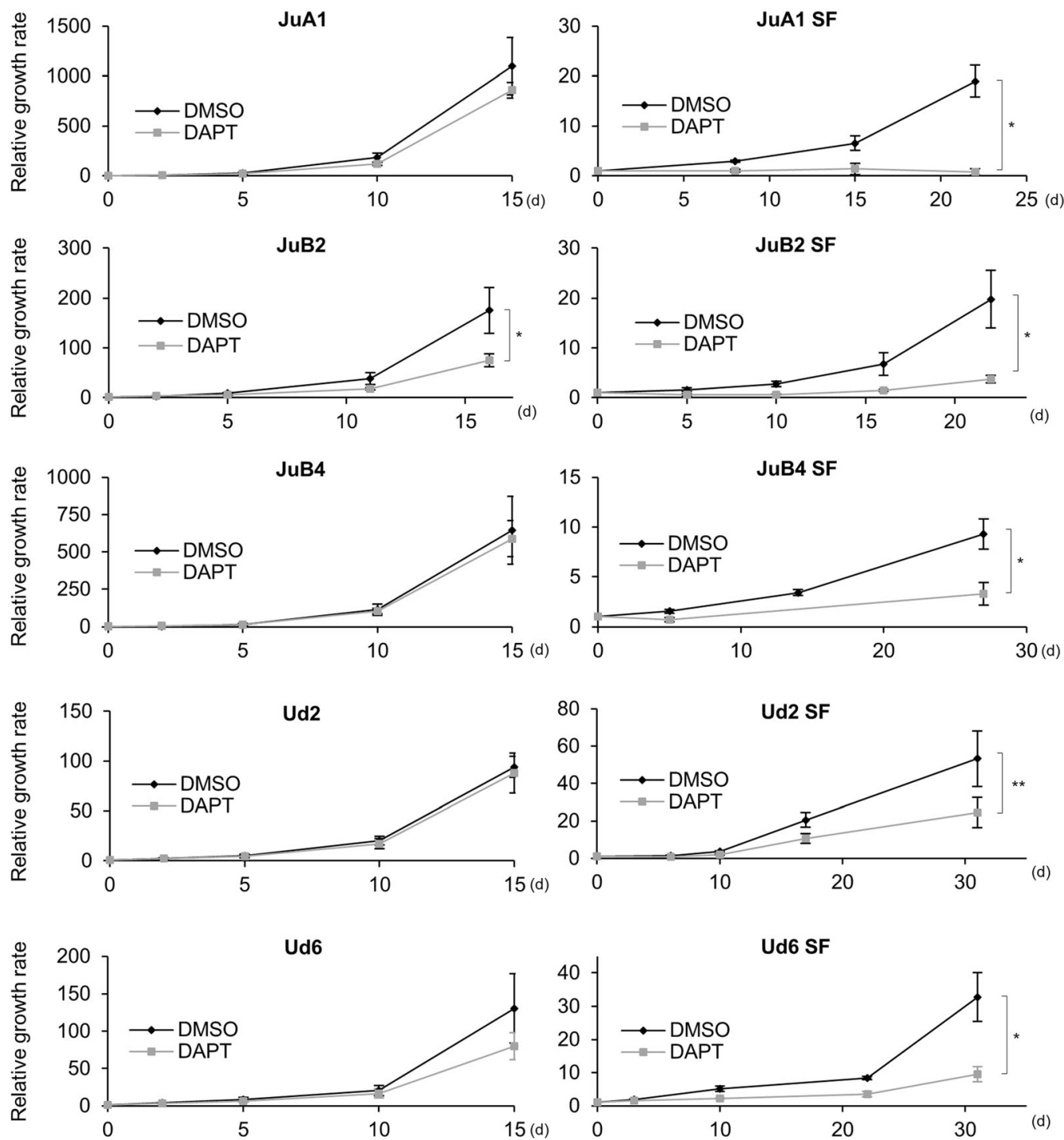

B
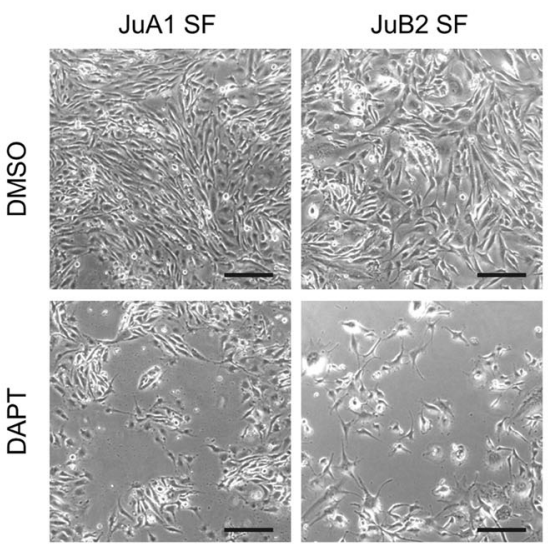

JuB4 SF

Ud2 SF

Ud6 SF

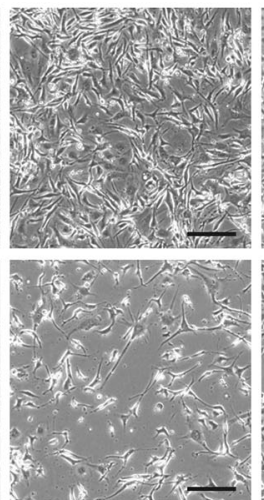

$5 d$

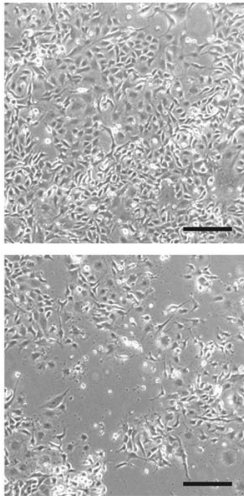

$6 \mathrm{~d}$

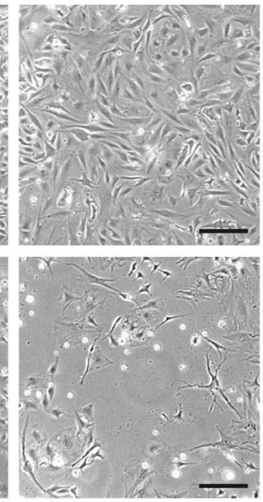

$9 \mathrm{~d}$

Fig. 5 a Relative growth rate of HSA cell lines cultured in normal or SF condition treated with DMSO or DAPT. ${ }^{*} p<0.01 .{ }^{* *} p<0.05$. Student's $t$ test. All samples were analyzed in triplicates and growth curves are presented as means \pm SD. b Representative images of HSA cell lines in serum-free condition treated with DAPT or not. Bars $=100 \mu \mathrm{m}$ 
Table $32^{-\Delta C t}$ values of NOTCH2 and NOTCH4

\begin{tabular}{lllllllllll}
\hline $2^{-\Delta C t}$ & JuA1 & JuA1 SF & JuB2 & JuB2 SF & JuB4 & JuB4 SF & Ud2 & Ud2 SF & Ud6 & Ud6 SF \\
\hline NOTCH2 & 0.0179 & 0.0618 & 0.2430 & 1.0862 & 0.2346 & 1.4135 & 0.0828 & 0.9478 & 0.9553 & 1.0772 \\
NOTCH4 & 0.0606 & 0.1553 & 0.0002 & 0.0053 & 0.0009 & 0.0240 & 0.0052 & 0.0801 & 0.0009 & 0.0084 \\
\hline
\end{tabular}

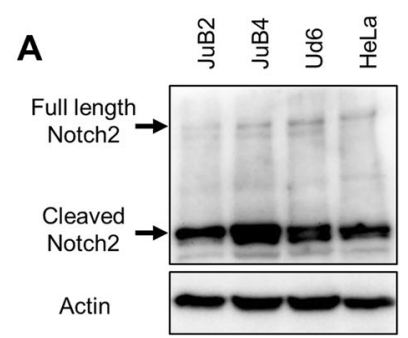

C

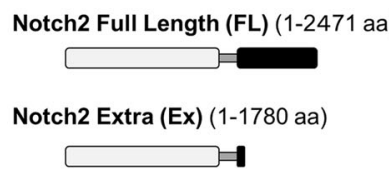

Notch2 Intra (In) (1721-2471 aa)
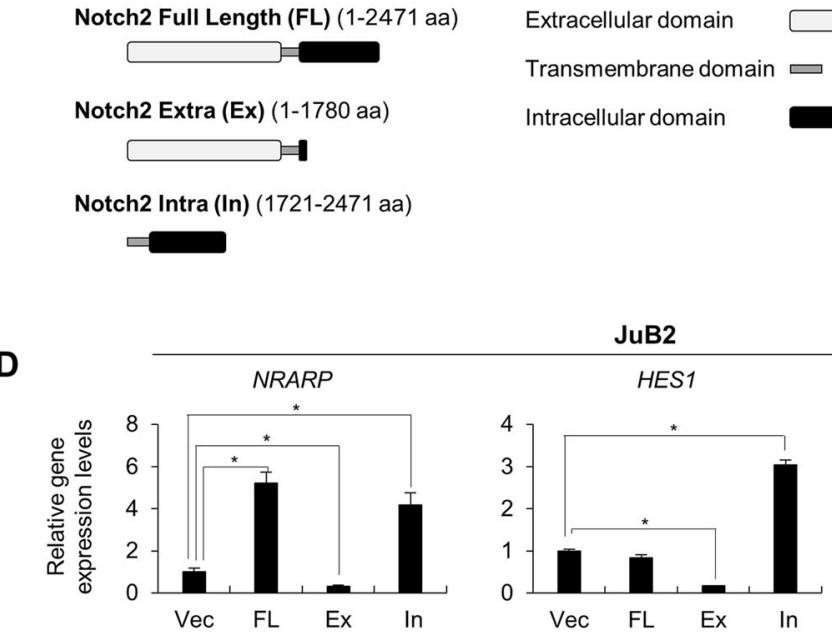

Intracellular domain
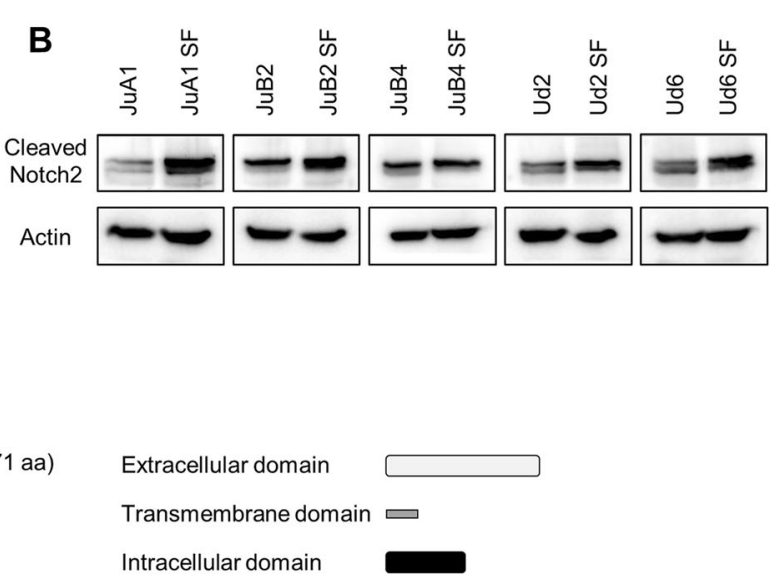
A
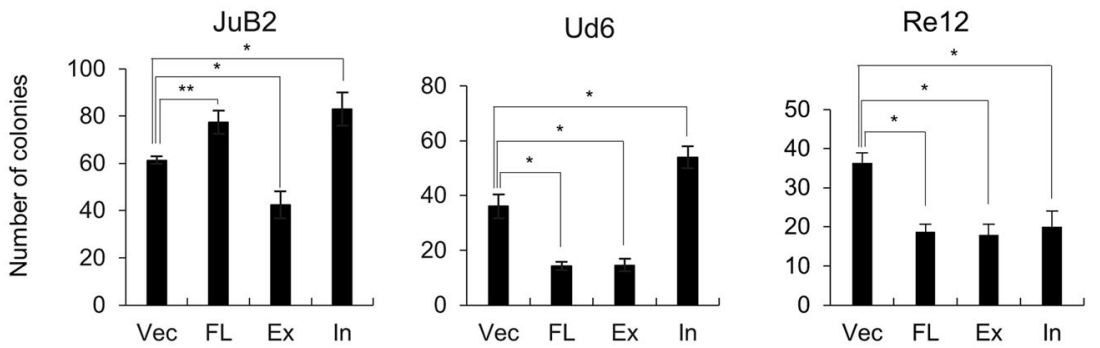

B Vec

$\mathrm{FL}$

Ex

$\ln$
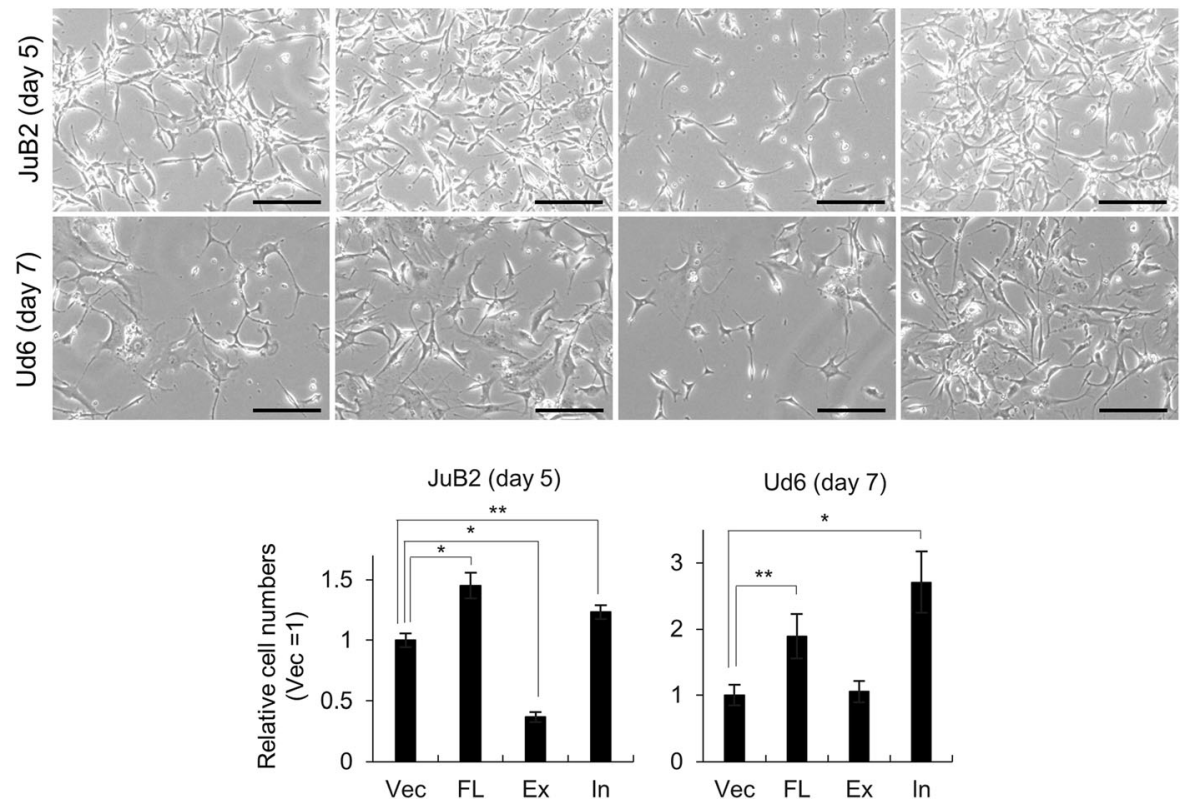

Fig. 7 a Colony numbers of HSA cell lines overexpressing Notch2 vector constructs. b (Top) Representative images of JuB2 and Ud6, 5 and 7 days after starting serum-free culture, respectively. Bars $=100 \mu \mathrm{m}$. (Bottom) Relative cell numbers of JuB2 and Ud6. Number of Vec was set to 1. ${ }^{*} p<0.01 .{ }^{* *} p<0.05$. Dunnett's test. The scores are presented as means \pm SD

Notch2 expression from these constructs were confirmed using anti-FLAG antibody and anti-Notch2 antibody (Additional file 5: Figure S5). After establishment of stable cell lines, we analyzed Notch signal target genes, NRARP, HES1 and $H E Y 2$ to confirm the functions of wild type and mutant Notch2 in stable cell lines. JuB2 and Ud6, where we succeeded in isolating CSC-like cells with SF culture, showed significantly higher expressions of these target genes in cells overexpressing FL and In, and significantly lower expressions in cells overexpressing Ex compared to vector controls (Vec) (Fig. 6d). In contrast, Re12 did not show any upregulation of the target genes' expression in cells overexpressing FL and In although Ex overexpression in Re12 repressed them. Next, we checked the effects of Notch2 on clonogenicity using CFA, which resulted in the significant increase of colony numbers in In-overexpressing cells and significant decrease in Ex-overexpressing cells in both JuB2 and Ud6 cells, on the other hand, the colony formation was significantly decreased in Re12 overexpressing any types of Notch2 (Fig. 7a). Lastly, we checked whether Notch2 inhibition or activation affected CSC-like cell numbers after changing culture condition from normal to SF. As a result, Notch2 inhibition by Ex overexpression significantly decreased the number of viable cells in JuB2, while, Notch2 activation by FL- and In-overexpression resulted to significantly increased number of viable cells in JuB2 and Ud6 cell lines (Fig. 7b). These results suggest that Notch2 signal is required for the maintenance of HSA CSC-like cells.

\section{Notch2 is highly expressed in clinical HSA cases}

We analyzed Notch2 expression in clinical HSA cases with IHC. Twelve HSA cases were tested and all cases were positive for anti-Notch2 antibody (Fig. 8). Stronger staining intensities were observed in neoplastic cells 


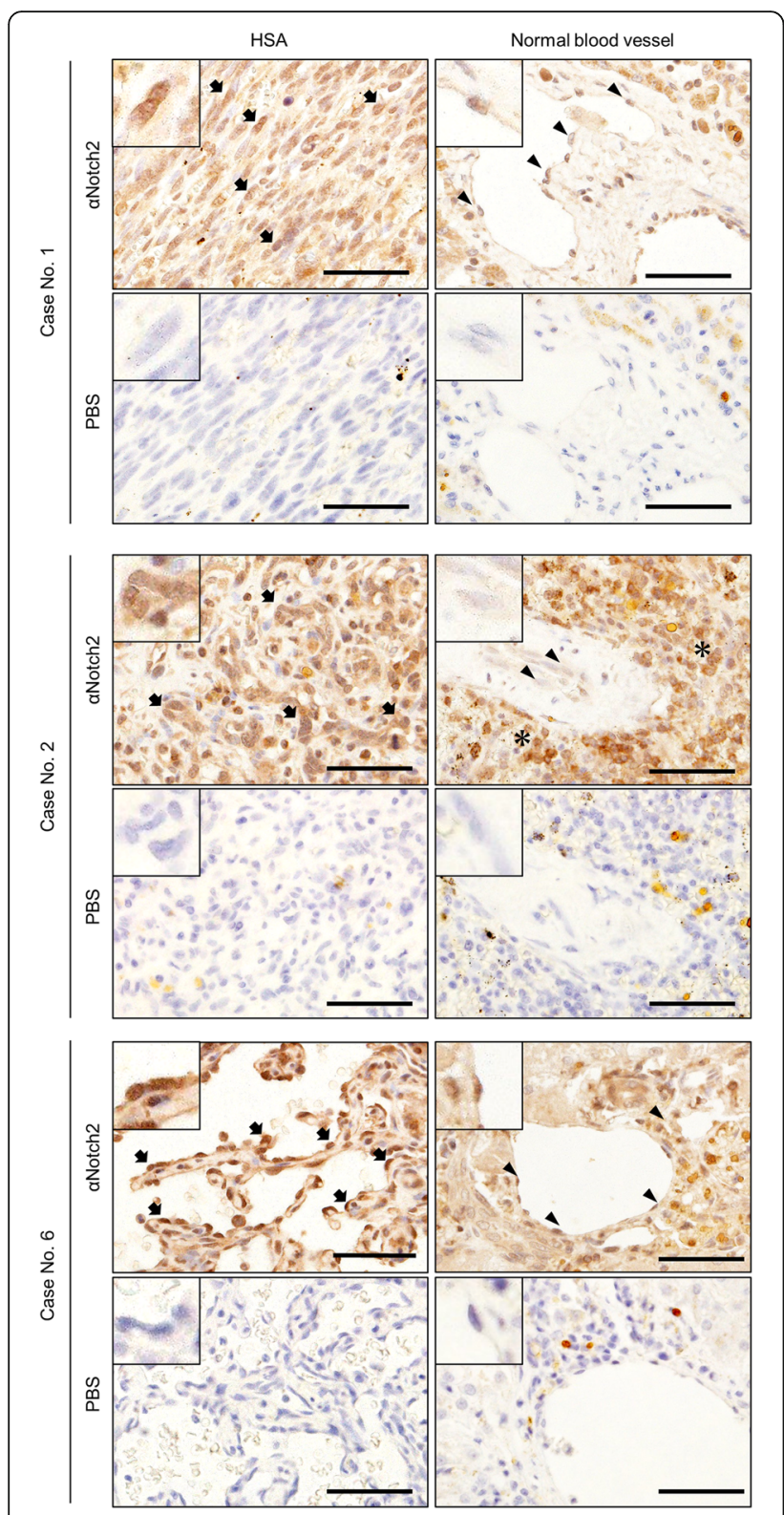

Fig. 8 Immunohistochemistry analysis for clinical HSA cases using antihuman Notch2 antibody. Insertion indicated the magnified views of tumor cells or normal endothelial cells. Arrows = neoplastic cells. Arrow heads $=$ endothelial cells in normal blood vessels in the same slides. Asterisks $=$ lymphocytes. Bars $=50 \mu \mathrm{m}$

compared to the endothelial cells of normal blood vessels in the same slide. The staining intensities of tumor cells were at the same level with lymphocytes, a positive control for Notch2 (Fig. 8 case No.2). These results suggest that Notch 2 is also active in clinical HSA cases.

\section{Discussion}

In this study, we found that Notch2 is a key factor for the maintenance of HSA CSC-like cells. Isolated cells from our serum-free culture method had CSC-like characteristics such as upregulation of undifferentiated endothelial cell markers, high clonogenicity, high drug resistance, and increased $\mathrm{ALDH}^{+}$cell population. Constitutive activation of Notch2 resulted to an increase of the number of cells with high clonogenicity in normal culture condition and cells which can survive in SF condition, while Notch2 inhibition caused opposite effects. Furthermore, Notch2 was found to be highly expressed and active in clinical HSA cases.

We succeeded in culturing CSC-like cells from Ju and Ud cell lines but, unfortunately, we were not able to isolate CSC-like cells from Re cell lines (Re12 and Re21). Furthermore, any types of Notch2 overexpression in Re12 repressed downstream gene expressions and colony formation. Re cell lines were derived from HSA in the right atrium of the heart of a Golden retriever [33, 53]. Several reports have indicated that HSA of Golden retrievers has different characteristics from those of other breeds [54-56]. Tamburini et al. have demonstrated that significant upregulation of VEGFR1 was observed in HSA from Golden retrievers compared to other breeds [54]. Vegfr1 is a tyrosine kinase receptor which can bind to an angiogenic factor Vegfa. It was thought as a decoy receptor for Vegfr2 which has higher tyrosine kinase activity than Vegfr1 and works as a major transducer of Vegfa. However, it has recently been reported that Vegfr1 can also transduce signals and stimulates tumor growth and metastasis [57]. Vegfr2 has different signal transductions from Vegfr1 and induces angiogenesis specifically by regulating Ets1 transcription factor [58]. Those different signal transductions and transcriptional regulation probably give different characteristics to HSA in Golden Retrievers. Further research comparing the molecular biology of HSA from Golden Retrievers and other breeds is required.

Notch2 is one of the Notch signal receptors and has been reported as an important factor both for tumorigenesis and stem cell maintenance. Active mutations in NOTCH2 are involved in developments of diffuse large $\mathrm{B}$ cell lymphoma and marginal zone B-cell lymphoma [59-62]. In human hepatocellular carcinoma, Notch2 regulates the stemness of liver CSCs via upregulation of NRARP, HES1 and HES6 [63]. Notch2 is also highly upregulated in pancreatic cancer-stem cells [64]. In our study, activation of Notch2 by FL and In in JuB2 increased the number of colonies observed in CFA and survival cell numbers in SF condition, and Notch signal inhibition by Ex indicated opposite effects. Ud6 overexpressing In had similar results with JuB2, but Ud6 cells overexpressing FL or Ex showed different results wherein the cells overexpressing FL had decreased number of colonies while those overexpressing Ex showed no difference with vector control even after changing to SF culture medium. The discrepancy between JuB2 and 
Ud6 both of which expressed FL is probably resulted from the difference in the amount of ligands which can trigger Notch signals. In, the constitutive active form, overexpression showed increase in number of colonies and survival of cells in either experiment. There may not be enough number of cells secreting ligands in Ud6 in normal cell culture condition. Negative feedback system of Notch signaling may also be related [65]. In Ud6 cells overexpressing Ex, other factors such as other Notch receptors may compensate for the loss of function of Notch2 in SF condition. Notch2 may be important for stemness maintenance in HSA, however, we could not identify its responsible ligands and direct targets. Further experiments which focus on the targets of Notch2 to maintain stemness in HSA are warranted. Also, since NOTCH4 was also highly upregulated in SF condition, it is worth analyzing its function for cell survival in SF condition.

Although we can't exclude the possibility that Notch signal was just artificially activated by stimulating the Fgf pathway and gelatin coating, we speculate that our culture condition imitates the microenvironment for hemangiosarcoma cancer stem cells. In general, microenvironment is required to maintain stem cells in their undifferentiated state by transducing signals and/or by providing cytokines. Neoplastic cells can be differentiated when they go out of the microenvironment [12]. Based on this nature, imitating suitable microenvironment is necessary to culture cancer stem cell-like cells even in vitro condition. However, further experiments to analyze Fgf pathway activity including Fgf receptor and ligand expression in tumor cells and in microenvironment components such as inflammatory cells and fibroblasts are required.

\section{Conclusions}

In conclusion, we succeeded in isolating CSC-like cells in HSA using our own method, and demonstrated that Notch2 is a key factor for the maintenance of HSA CSC-like cells. Our study can encourage further stem cell research in HSA and may provide a way to develop effective treatments targeting CSCs.

\section{Additional files}

Additional file 1: Figure S1. Standard curves for each primer. Slope was used to calculate primer efficiencies. (TIF $801 \mathrm{~kb}$ )

Additional file 2: Figure S2. Standard curves for each primer. Slope was used to calculate primer efficiencies. (TIF $794 \mathrm{~kb}$ )

Additional file 3: Figure S3. Results of geNorm analysis for reference gene candidates. To determine optimal number of reference genes, $0.15 V$ value was used as the cut-off value as Vandesompele et al. [38] recommended. (TIF $1355 \mathrm{~kb}$ )

Additional file 4: Figure S4. Gene expression levels of Notch signal target genes. HSA cells treated with DMSO were set to $1 .{ }^{*} p<0.01 .{ }^{* *} p<$ 0.05. Dunnett's test. (TIF $576 \mathrm{~kb}$ )
Additional file $\mathbf{5}$ Figure S5. Western blot analysis to detect Notch2 constructs expressions using anti-FLAG antibody (A) and anti-Notch2 antibody (B). Since anti-Notch2 antibody that we used can detect the Notch2 intracellular domain, the Notch2 Ex was not detected. Vec = cells transfected the empty vector. FL = cells overexpressing full length of Notch2. Ex $=$ cells overexpressing dominant negative form of Notch2. In = cells overexpressing constitutive active form of Notch2. (TIF $1028 \mathrm{~kb}$ )

\section{Abbreviations}

ALDH: Aldehyde dehydrogenase; bFGF: Basic fibroblast growth factor; CFA: Colony formation assay; CnAOEC: Canine Aortic Endothelial Cells; CSCs: Cancer stem cells; DAPT: N-[N-(3,5-Difluorophenacetyl)-L-alanyl]-Sphenylglycine t-butyl estel; DEAB: N,N-diethylaminobenzaldehyde; DMEM: Dulbecco's Modified Eagle's Medium; DMSO: Dimethyl sulfoxide; EGF: Epidermal growth factor; Ex: Notch2 dominant negative form; FL: Notch2 full length form; HSA: Hemangiosarcoma;

IHC: Immunohistochemistry; In: Notch2 constitutive active form; PBS: Phosphate buffered saline; PCR: Polymerase chain reaction; PVDF: Polyvinylidene difluoride membrane; RiPA

buffer: Radioimmunoprecipitation buffer; RT: Room temperature; RTqPCR: Reverse transcription quantitative polymerase chain reaction; SDS: Sodium dodecyl sulfate; SF: Serum-free; SIN: Self-inactivating; TBST: Trisbuffered saline containing 0.05\% Tween 20; UPDW: UltraPure DNase/RNasefree distilled water

\section{Acknowledgements}

We would like to extend our sincerest gratitude to Dr. Hiroki Sakai (Gifu University) for providing canine hemangiosarcoma cell lines, and to Dr. Hiroyuki Miyoshi (RIKEN BioResource Research Center) for providing lentiviral vector constructs. We also acknowledge the efforts of Dr. Jumpei Yamazaki and Mr. Shinichi Onishi for giving useful pieces of advice and constructive discussion. We are grateful to all the members of the Laboratory of Comparative Pathology, Faculty of Veterinary Medicine, Hokkaido University for their helpful discussions, encouragements, and support.

\section{Funding}

This research was supported by JSPS KAKENHI Grant-in-Aid for Young Scientist (Number 18K14575), a Grants-in-Aid for Regional R\&D Proposal-Based Program from Northern Advancement Center for Science \& Technology of Hokkaido, Japan and a grant from The Akiyama Life Science Foundation.

\section{Availability of data and materials}

The datasets used and/or analyzed during the current study are available from the corresponding author on reasonable request.

\section{Authors' contributions}

KA conceived and designed the experiments. KA, YF, OE and AM performed experiments and analyzed the data. KA, KCMG, AK and TK wrote the manuscripts. All authors read and approved the final manuscript.

\section{Ethics approval and consent to participate}

Ethics approval was not required to use 293 T cells and HeLa cells in Hokkaido University because these cell lines can be purchased from companies and are widely used in research fields. Ethics approval is also not required to use non-human cell lines including canine cell lines in Hokkaido University. Written informed consents were obtained from the owners of the dogs with hemangiosarcoma for the samples to be used for research purposes.

\section{Consent for publication}

Not applicable.

\section{Competing interests}

The authors declare that they have no competing interests.

\section{Publisher's Note}

Springer Nature remains neutral with regard to jurisdictional claims in published maps and institutional affiliations. 


\section{Received: 10 July 2018 Accepted: 24 September 2018} Published online: 03 October 2018

\section{References}

1. Meuten DJ. Tumors in domestic animals. 5th ed. Ames: Wiley/Blackwell; 2017

2. Young RJ, Brown NJ, Reed MW, Hughes D, Woll PJ. Angiosarcoma. Lancet Oncol. 2010;11(10):983-91.

3. Brown NO, Patnaik AK, MacEwen EG. Canine hemangiosarcoma: retrospective analysis of 104 cases. J Am Vet Med Assoc. 1985:186(1):56-8.

4. Kim JH, Graef AJ, Dickerson EB, Modiano JF. Pathobiology of Hemangiosarcoma in Dogs: Research Advances and Future Perspectives. Vet Sci. 2015;2(4):388-405.

5. Pearson GR, Head KW. Malignant haemangioendothelioma (angiosarcoma) in the dog. J Small Anim Pract. 1976;17(11):737-45.

6. Goritz M, Muller K, Krastel D, Staudacher G, Schmidt P, Kuhn M, Nickel R, Schoon HA. Canine splenic haemangiosarcoma: influence of metastases, chemotherapy and growth pattern on post-splenectomy survival and expression of angiogenic factors. J Comp Pathol. 2013;149(1):30-9.

7. Smith AN. Hemangiosarcoma in dogs and cats. Vet Clin North Am Small Anim Pract. 2003:33(3):533-52 vi.

8. Ogilvie GK, Powers BE, Mallinckrodt CH, Withrow SJ. Surgery and doxorubicin in dogs with hemangiosarcoma. J Vet Intern Med. 1996;10(6): 379-84

9. Wendelburg KM, Price LL, Burgess KE, Lyons JA, Lew FH, Berg J. Survival time of dogs with splenic hemangiosarcoma treated by splenectomy with or without adjuvant chemotherapy: 208 cases (2001-2012). J Am Vet Med Assoc. 2015;247(4):393-403.

10. Olson RD, Mushlin PS, Brenner DE, Fleischer S, Cusack BJ, Chang BK, Boucek RJ Jr. Doxorubicin cardiotoxicity may be caused by its metabolite, doxorubicinol. Proc Natl Acad Sci U S A. 1988;85(10):3585-9.

11. Hammer AS, Couto CG, Filppi J, Getzy D, Shank K. Efficacy and toxicity of VAC chemotherapy (vincristine, doxorubicin, and cyclophosphamide) in dogs with hemangiosarcoma. J Vet Intern Med. 1991;5(3):160-6.

12. Batlle E, Clevers H. Cancer stem cells revisited. Nat Med. 2017;23(10):1124-34.

13. Jin X, Jin X, Kim H. Cancer stem cells and differentiation therapy. Tumour Biol. 2017;39(10):1010428317729933.

14. Chen $\mathrm{K}$, Huang $\mathrm{YH}$, Chen JL. Understanding and targeting cancer stem cells: therapeutic implications and challenges. Acta Pharmacol Sin. 2013;34(6): 732-40.

15. Dragu DL, Necula LG, Bleotu C, Diaconu CC, Chivu-Economescu M. Therapies targeting cancer stem cells: Current trends and future challenges. World J Stem Cells. 2015;7(9):1185-201.

16. Bonnet D, Dick JE. Human acute myeloid leukemia is organized as a hierarchy that originates from a primitive hematopoietic cell. Nat Med. 1997;3(7):730-7

17. Al-Hajj M, Wicha MS, Benito-Hernandez A, Morrison SJ, Clarke MF. Prospective identification of tumorigenic breast cancer cells. Proc Natl Acad Sci U S A. 2003;100(7):3983-8.

18. Fang D, Nguyen TK, Leishear K, Finko R, Kulp AN, Hotz S, Van Belle PA, Xu X, Elder DE, Herlyn M. A tumorigenic subpopulation with stem cell properties in melanomas. Cancer Res. 2005;65(20):9328-37.

19. Artavanis-Tsakonas S, Rand MD, Lake RJ. Notch signaling: cell fate control and signal integration in development. Science. 1999;284(5415):770-6.

20. Hori K, Sen A, Artavanis-Tsakonas S. Notch signaling at a glance. J Cell Sci. 2013:126(Pt 10):2135-40

21. Serra H, Chivite I, Angulo-Urarte A, Soler A, Sutherland JD, ArruabarrenaAristorena A, Ragab A, Lim R, Malumbres M, Fruttiger M, et al. PTEN mediates Notch-dependent stalk cell arrest in angiogenesis. Nat Commun. 2015:6:7935

22. Xiao W, Gao Z, Duan Y, Yuan W, Ke Y. Notch signaling plays a crucial role in cancer stem-like cells maintaining stemness and mediating chemotaxis in renal cell carcinoma. J Exp Clin Cancer Res. 2017;36(1):41

23. Klinakis A, Lobry C, Abdel-Wahab O, Oh P, Haeno H, Buonamici S, van De Walle I, Cathelin S, Trimarchi T, Araldi E, et al. A novel tumour-suppressor function for the Notch pathway in myeloid leukaemia. Nature. 2011 473(7346):230-3

24. Kopan R, llagan MX. The canonical Notch signaling pathway: unfolding the activation mechanism. Cell. 2009:137(2):216-33.

25. Yamamoto M, Taguchi Y, Ito-Kureha T, Semba K, Yamaguchi N, Inoue J. NFkappaB non-cell-autonomously regulates cancer stem cell populations in the basal-like breast cancer subtype. Nat Commun. 2013;4:2299.
26. Gonzalez ME, Moore HM, Li X, Toy KA, Huang W, Sabel MS, Kidwell KM, Kleer CG. EZH2 expands breast stem cells through activation of NOTCH1 signaling. Proc Natl Acad Sci U S A. 2014;111(8):3098-103.

27. Hovinga KE, Shimizu F, Wang R, Panagiotakos G, Van Der Heijden M, Moayedpardazi H, Correia AS, Soulet D, Major T, Menon J, et al. Inhibition of notch signaling in glioblastoma targets cancer stem cells via an endothelial cell intermediate. Stem Cells. 2010;28(6):1019-29.

28. Su Q, Xin L. Notch signaling in prostate cancer: refining a therapeutic opportunity. Histol Histopathol. 2016;31(2):149-57.

29. Baghdadi MB, Castel D, Machado L, Fukada SI, Birk DE, Relaix F, Tajbakhsh S, Mourikis $P$. Reciprocal signalling by Notch-Collagen V-CALCR retains muscle stem cells in their niche. Nature. 2018;557(7707):714-8.

30. Dill MT, Rothweiler S, Djonov V, Hlushchuk R, Tornillo L, Terracciano L, MeiliButz S, Radtke F, Heim MH, Semela D. Disruption of Notch1 induces vascular remodeling, intussusceptive angiogenesis, and angiosarcomas in livers of mice. Gastroenterology. 2012;142(4):967-977.e2.

31. Kluk MJ, Ashworth T, Wang H, Knoechel B, Mason EF, Morgan EA, Dorfman D, Pinkus G, Weigert O, Hornick JL, et al. Gauging NOTCH1 Activation in Cancer Using Immunohistochemistry. PLoS One. 2013;8(6):e67306.

32. Panse G, Chrisinger JS, Leung CH, Ingram DR, Khan S, Wani K, Lin H, Lazar AJ, Wang WL. Clinicopathological analysis of ATRX, DAXX and NOTCH receptor expression in angiosarcomas. Histopathology. 2018;72(2):239-47.

33. Murai A, Asa SA, Kodama A, Hirata A, Yanai T, Sakai H. Constitutive phosphorylation of the mTORC2/Akt/4E-BP1 pathway in newly derived canine hemangiosarcoma cell lines. BMC Vet Res. 2012;8:128.

34. Pollard SM, Yoshikawa K, Clarke ID, Danovi D, Stricker S, Russell R, Bayani J, Head R, Lee M, Bernstein M, et al. Glioma stem cell lines expanded in adherent culture have tumor-specific phenotypes and are suitable for chemical and genetic screens. Cell Stem Cell. 2009;4(6):568-80.

35. Scheel C, Eaton EN, Li SH, Chaffer CL, Reinhardt F, Kah K, Bell G, Guo W, Rubin J, Richardson AL, et al. Paracrine and autocrine signals induce and maintain mesenchymal and stem cell states in the breast. Cell. 2011;145(6):926-40.

36. Kobayashi S, Yamada-Okabe H, Suzuki M, Natori O, Kato A, Matsubara K, Jau Chen Y, Yamazaki M, Funahashi S, Yoshida K, et al. LGR5-positive colon cancer stem cells interconvert with drug-resistant LGR5-negative cells and are capable of tumor reconstitution. Stem Cells. 2012;30(12):2631-44.

37. Kimura T, Wang L, Tabu K, Tsuda M, Tanino M, Maekawa A, Nishihara H, Hiraga $H$, Taga $T$, Oda $Y$, et al. Identification and analysis of CXCR4-positive synovial sarcoma-initiating cells. Oncogene. 2016;35(30):3932-43.

38. Vandesompele J, De Preter K, Pattyn F, Poppe B, Van Roy N, De Paepe A, Speleman F. Accurate normalization of real-time quantitative RT-PCR data by geometric averaging of multiple internal control genes. Genome Biol. 2002;3(7):RESEARCH0034.

39. Peters IR, Peeters D, Helps CR, Day MJ. Development and application of multiple internal reference (housekeeper) gene assays for accurate normalisation of canine gene expression studies. Vet Immunol Immunopathol. 2007;117(1-2):55-66.

40. Dailey DD, Anfinsen KP, Pfaff LE, Ehrhart EJ, Charles JB, Bonsdorff TB, Thamm $\mathrm{DH}$, Powers BE, Jonasdottir TJ, Duval DL. HES1, a target of Notch signaling, is elevated in canine osteosarcoma, but reduced in the most aggressive tumors. BMC Vet Res. 2013;9:130

41. Rafehi H, Orlowski C, Georgiadis GT, Ververis K, El-Osta A, Karagiannis TC. Clonogenic assay: adherent cells. J Vis Exp. 2011;(49):2573.

42. NCl-60 Screening Methodology. Discovery \& Development Services | DTP. https://dtp.cancer.gov/discovery_development/nci-60/methodology.htm. Accessed 31 Jan 2018

43. Schneider CA, Rasband WS, Eliceiri KW. NIH Image to ImageJ: 25 years of image analysis. Nat Methods. 2012;9(7):671-5.

44. Schindelin J, Arganda-Carreras I, Frise E, Kaynig V, Longair M, Pietzsch T, Preibisch S, Rueden C, Saalfeld S, Schmid B, et al. Fiji: an open-source platform for biological-image analysis. Nat Methods. 2012;9(7):676-82.

45. Rueden $C T$, Schindelin J, Hiner MC, DeZonia BE, Walter AE, Arena ET, Eliceiri KW. ImageJ2: ImageJ for the next generation of scientific image data. BMC Bioinformatics. 2017:18(1):529.

46. Zeuner A, Francescangeli F, Signore M, Venneri MA, Pedini F, Felli N, Pagliuca A, Conticello C, De Maria R. The Notch2-Jagged1 interaction mediates stem cell factor signaling in erythropoiesis. Cell Death Differ. 2011;18(2):371-80.

47. Maharani A, Aoshima K, Onishi S, Gulay KCM, Kobayashi A, Kimura T. Cellular atypia is negatively correlated with immunohistochemical reactivity of CD31 and VWF expression levels in canine hemangiosarcoma. J Vet Med Sci. 2018 $80(2): 213-8$ 
48. Ginsberg M, James D, Ding BS, Nolan D, Geng F, Butler JM, Schachterle W, Pulijaal VR, Mathew S, Chasen ST, et al. Efficient direct reprogramming of mature amniotic cells into endothelial cells by ETS factors and TGFbeta suppression. Cell. 2012;151(3):559-75.

49. Yu QC, Song W, Wang D, Zeng YA. Identification of blood vascular endothelial stem cells by the expression of protein $C$ receptor. Cell Res. 2016;26(10):1079-98.

50. Kanki Y, Nakaki R, Shimamura T, Matsunaga T, Yamamizu K, Katayama S, Suehiro Jl, Osawa T, Aburatani H, Kodama T, et al. Dynamically and epigenetically coordinated GATA/ETS/SOX transcription factor expression is indispensable for endothelial cell differentiation. Nucleic Acids Res. 2017; 45(8):4344-58.

51. Korkaya H, Paulson A, lovino F, Wicha MS. HER2 regulates the mammary stem/progenitor cell population driving tumorigenesis and invasion. Oncogene. 2008;27(47):6120-30.

52. Croker AK, Goodale D, Chu J, Postenka C, Hedley BD, Hess DA, Allan AL. High aldehyde dehydrogenase and expression of cancer stem cell markers selects for breast cancer cells with enhanced malignant and metastatic ability. J Cell Mol Med. 2009;13(8B):2236-52.

53. Kodama A, Sakai H, Matsuura S, Murakami M, Murai A, Mori T, Maruo K, Kimura T, Masegi T, Yanai T. Establishment of canine hemangiosarcoma xenograft models expressing endothelial growth factors, their receptors, and angiogenesis-associated homeobox genes. BMC Cancer. 2009;9:363.

54. Tamburini BA, Trapp S, Phang TL, Schappa JT, Hunter LE, Modiano JF. Gene expression profiles of sporadic canine hemangiosarcoma are uniquely associated with breed. PLoS One. 2009;4(5):e5549.

55. Tamburini BA, Phang TL, Fosmire SP, Scott MC, Trapp SC, Duckett MM, Robinson SR, Slansky JE, Sharkey LC, Cutter GR, et al. Gene expression profiling identifies inflammation and angiogenesis as distinguishing features of canine hemangiosarcoma. BMC Cancer. 2010;10:619.

56. Tonomura N, Elvers I, Thomas R, Megquier K, Turner-Maier J, Howald C, Sarver AL, Swofford R, Frantz AM, Ito D, et al. Genome-wide association study identifies shared risk loci common to two malignancies in golden retrievers. PLoS Genet. 2015;11(2):e1004922.

57. Shibuya M. Involvement of Flt-1 (VEGF receptor-1) in cancer and preeclampsia. Proc Jpn Acad Ser B Phys Biol Sci. 2011;87(4):167-78.

58. Koch $\mathrm{S}$, Claesson-Welsh L. Signal transduction by vascular endothelial growth factor receptors. Cold Spring Harb Perspect Med. 2012;2(7):a006502.

59. Lee SY, Kumano K, Nakazaki K, Sanada M, Matsumoto A, Yamamoto G, Nannya Y, Suzuki R, Ota S, Ota Y, et al. Gain-of-function mutations and copy number increases of Notch2 in diffuse large B-cell lymphoma. Cancer Sci. 2009;100(5):920-6.

60. Rossi D, Trifonov V, Fangazio M, Bruscaggin A, Rasi S, Spina V, Monti S, Vaisitti T, Arruga F, Fama R, et al. The coding genome of splenic marginal zone lymphoma: activation of NOTCH2 and other pathways regulating marginal zone development. J Exp Med. 2012;209(9):1537-51.

61. Arcaini L, Rossi D, Lucioni M, Nicola M, Bruscaggin A, Fiaccadori V, Riboni R, Ramponi A, Ferretti W, Cresta S, et al. The NOTCH pathway is recurrently mutated in diffuse large B-cell lymphoma associated with hepatitis $C$ virus infection. Haematologica. 2015;100(2):246-52.

62. Kiel MJ, Velusamy T, Betz BL, Zhao L, Weigelin HG, Chiang MY, HuebnerChan DR, Bailey NG, Yang DT, Bhagat G, et al. Whole-genome sequencing identifies recurrent somatic NOTCH2 mutations in splenic marginal zone lymphoma. J Exp Med. 2012;209(9):1553-65.

63. Zhu P, Wang Y, Du Y, He L, Huang G, Zhang G, Yan X, Fan Z. C8orf4 negatively regulates self-renewal of liver cancer stem cells via suppression of NOTCH2 signalling. Nat Commun. 2015;6:7122.

64. Zhou ZC, Dong QG, Fu DL, Gong YY, Ni QX. Characteristics of Notch2(+) pancreatic cancer stem-like cells and the relationship with centroacinar cells. Cell Biol Int. 2013;37(8):805-11.

65. Lamar E, Deblandre G, Wettstein D, Gawantka V, Pollet N, Niehrs C, Kintner C. Nrarp is a novel intracellular component of the Notch signaling pathway. Genes Dev. 2001;15(15):1885-99.

\section{Ready to submit your research? Choose BMC and benefit from:}

- fast, convenient online submission

- thorough peer review by experienced researchers in your field

- rapid publication on acceptance

- support for research data, including large and complex data types

- gold Open Access which fosters wider collaboration and increased citations

- maximum visibility for your research: over $100 \mathrm{M}$ website views per year

At BMC, research is always in progress.

Learn more biomedcentral.com/submissions 